\title{
Pulmonary wedge resection for clinical stage I non-small cell lung cancer: a review of a mini-invasive treatment
}

\author{
Noriyoshi Sawabata ${ }^{1}$, Akikazu Kawase $^{2}$, Nobumasa Takahashi ${ }^{3}$, Takeshi Kawaguchi ${ }^{4}$, Noriyuki Matsutani ${ }^{5}$ \\ ${ }^{1}$ General Thoracic Surgery, Hoshigaoka Medical Center, Osaka 873-8511, Japan. \\ ${ }^{2}$ First Department of Surgery, Hamamatsu Medical University School of Medicine, Shizuoka 431-3192, Japan. \\ ${ }^{3}$ Department of Respiratory Surgery Saitama Cardiovascular and Respiratory Center, Saitama 360-0105, Japan. \\ ${ }^{4}$ Department of Thoracic and Cardiovascular Surgery, Nara Medical University, Nara 634-8522, Japan. \\ ${ }^{5}$ Department of Surgery, Teikyo University School of Medicine, Tokyo 173-8605, Japan.
}

Correspondence to: Prof. Noriyoshi Sawabata, General Thoracic Surgery, Hoshigaoka Medical Center, Japan Community Healthcare Organization, 4-8-1 Hoshigaoka, Hirakata, Osaka 873-8511, Japan. E-mail: nsawabata@hotmail.com

How to cite this article: Sawabata N, Kawase A, Takahashi N, Kawaguchi T, Matsutani N. Pulmonary wedge resection for clinical stage I non-small cell lung cancer: a review of a mini-invasive treatment. Mini-invasive Surg 2017;1:12-23.

\author{
Article history: \\ Received: 05-01-2017 \\ Accepted: 13-03-2017 \\ Published: $31-03-2017$

\section{Key words:} \\ Non-small cell lung cancer, \\ wedge resection, \\ sublobar resection, \\ stage I, \\ stereotactic body radiation therapy
}

\begin{abstract}
Non-small cell lung cancer (NSCLC) is one of the leading causes of cancer-related deaths in the world. Therefore, there is a need to intensify treatments of these tumors. Because stage I NSCLC is a nonmetastatic disease, local therapies are indicated, among which surgery is the most commonly deployed strategy. Pulmonary wedge/sublobar resection is therefore discussed in comparison to stereotactic body radiation therapy for stage I lung cancer. Review of retrospective and prospective clinical trials reveal similar outcomes for both strategies, while a multicenter randomized prospective study comparing the efficacy of both therapies is on-going. Because the results of pulmonary wedge/sublobar resection may depend on tumor size, tumor-distance from surgical margin, tumor size-to-margin distance ratio, and margin cytology, prospective studies to evaluate the clinical implications of these factors, so as to inform patient prognostication, are recommended.
\end{abstract}

\section{INTRODUCTION}

The need for less invasive treatment strategies has been increasing, partly due to the increase in the ageing population. ${ }^{[1]}$ Because stage I lung cancer is a localized disease without evidence of metastases ${ }^{[2]}$ and is associated with low morbidity and mortality, minimally invasive (mini-invasive) local therapies are central to managing the high-risk or medically unfit patent such as the elderly. The various types of mini-invasive local therapies for stage I lung cancer are defined by the amount of lung tissue targeted or resected. These include segmentectomy and wedge resection (wedge/sublobar resection), radiation, radiofrequency ablation,,${ }^{[3,4]}$ and cryoablation therapies. ${ }^{[5]}$ Currently, the most commonly used strategies are wedge/sublobar resection and radiation therapy, including stereotactic body radiation therapy (SBRT). We therefore review pulmonary wedge/sublobar resection in comparison to SBRT for stage I lung cancer.

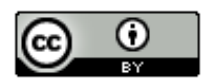
and reproduction

For reprints contact: service@oaepublish.com

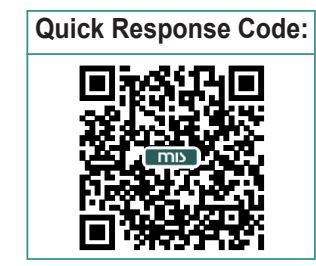


In order to retrieve articles, the author (N. S.) searched "PubMed" using key words relevant to the context of this review. Specifically, in addition to "lung cancer" and "stage I", either "wedge" or "SBRT" was chosen as key words. Incorporating the terms "wedge" and "SBRT", found a total of 169 and 250 articles, respectively. The author read the abstracts to select appropriate articles, which were then read in full. Article references were checked for useful studies that were not detected via "PubMed" searches.

Limited pulmonary resection varies such that making a distinction between segmentectomy and wedge resection can sometimes be difficult. Some segmentectomies fall under wedge resection; however, others with large amounts of resected pulmonary parenchyma are similar to lobectomy. Therefore, in this review, sublobar and wedge resections are discussed together. All contributors read the draft manuscript for comments, and when necessary, issues presented in the text were rewritten after discussion.

\section{RETROSPECTIVE STUDIES}

\section{Pulmonary wedge resection for solid lesions}

Stage I lung cancer comprises tumors that are not larger than $5 \mathrm{~cm}$ in diameter. It is usually technically difficult to achieve complete tumor removal by wedge resection for stage I tumors that are $5 \mathrm{~cm}$ in size (T2ANOMO; stage IB). It has therefore been speculated that such cases were excluded from retrospective analyses of pulmonary wedge resections for solid lesions. In addition, although the main subtypes of non-small cell lung cancer (NSCLC), adenocarcinoma, squamous cell carcinoma, and large-cell neuroendocrine carcinoma are associated with different prognosis, there are a few studies of pulmonary wedge resections for these tumors.

Among patients with early stage NSCLC, the rates of operative morbidity and mortality were reported to be lowest in those who underwent wedge resection, followed by segmentectomy, and then lobectomy. This was the conclusion of a study that aimed at investigating the grade of invasiveness of pulmonary wedge resection, segmentectomy, and lobectomy using registry data. Linden et al. ${ }^{[6]}$ therefore state that the Society of Thoracic Surgery database was reviewed for stage I and II NSCLC patients undergoing wedge resection and anatomic resection to analyze postoperative morbidity and mortality. Propensity scores were estimated using a logistic model adjusted for a variety of risk factors. Between 2009 and 2011, 3,733 wedge resection and 3,733 anatomic resection patients were matched. The operative mortality was
$1.21 \%$ for wedge resection versus $1.93 \%$ for anatomic resection $(P=0.0118)$. Major morbidity occurred in $4.53 \%$ of wedge resection patients versus $8.97 \%$ of anatomic resection patients $(P<0.0001) .{ }^{[6]}$ They concluded that wedge resection has a $37 \%$ lower mortality and $50 \%$ lower major morbidity rate than anatomic resection and these perioperative benefits must be carefully weighed against the increase in loco-regional recurrence and possible decrease in long-term survival associated with the use of wedge resection for primary lung cancers. ${ }^{[6]}$

Reports before 2000 that studied stage I NSCLC patients who received wedge/sublobar pulmonary resection provide a calculated 5 -year overall survival rate $(5-Y S R)$ of $60-70 \%$, and a local recurrence rate of approximately $25 \% .{ }^{[7-9]}$ Errette et al. ${ }^{[8]}$ reported in 1985 that the 5-YSR of wedge resection and lobectomy cases were $69 \%$ and $75 \%$, respectively, which was not statistically significant. In the 1997 study of the efficacy of thoracoscopic surgery for stage I NSCLC, Landreneau et al. ${ }^{[9]}$ reported a 5-YSR of $58 \%, 65 \%$, and $70 \%$ for patients who received open wedge resection, video-assisted wedge resection, and lobectomy, respectively. Although the calculated survival rate was not statistically significant between the open and video-assisted wedge resection groups, there was a difference in the 5-YSR between the wedge resection and lobectomy groups due to a significantly greater non-cancer-related deaths that occurred within 5 years among the wedge resection group ( $38 \%$ vs. $18 \%, P=0.014)$.

The results of retrospective institutional studies of pulmonary wedge resections for stage I NSCLC published in the 2000s are summarized in Table 1. The mortality rate was very low; however, the longtime survival rate was inferior to reports before 2000, which were investigations based on non-biased patient populations, ${ }^{[10-13]}$ while the rate of local recurrence did not change. ${ }^{[13,14]}$ In addition, the 5-YSR was not different between the wedge/sublobar resection and lobectomy groups. ${ }^{[10,12,15]}$ There have also been detailed analyses based on parameters speculated to be indicators of prognosis. Kraev et al. ${ }^{[12]}$ reported on the long-time survival of patients who underwent pulmonary wedge resection and lobectomy. Of 215 lobectomy and 74 wedge resection patients matched for age, tumor size, and other comorbidities, there was a non-significant overall trend towards better survival times (mean survival time, 5.8 vs. 4.1 years, respectively; $P=0.112$ ). However, this trend gained significance in analysis of smaller cancers, where patients who underwent lobectomy had better survival times than those who underwent wedge resection for tumors less than $3 \mathrm{~cm}$ 
Table 1: Retrospective institutional study of pulmonary wedge resection for clinical stage I NSCLC from 2000 to 2010

\begin{tabular}{|c|c|c|c|c|c|c|c|c|c|c|c|c|c|}
\hline \multirow[b]{2}{*}{ Author } & \multirow[b]{2}{*}{ Year } & \multirow[b]{2}{*}{$n$} & \multirow[b]{2}{*}{$\begin{array}{l}\text { Age, } \\
\text { years }\end{array}$} & \multirow{2}{*}{$\begin{array}{c}\mathrm{T} 1 \mathrm{a}<2 \mathrm{~cm}, \\
n(\%)\end{array}$} & \multirow{2}{*}{$\begin{array}{c}\text { GGO } \\
\text { dominant }\end{array}$} & \multirow[b]{2}{*}{ OP } & \multirow{2}{*}{$\begin{array}{c}\text { Margin } \\
\text { positive }\end{array}$} & \multirow{2}{*}{$\begin{array}{c}\text { Mortality, } \\
n(\%)\end{array}$} & \multirow{2}{*}{$\begin{array}{l}\text { Local } \\
\text { relapse, } \\
n(\%)\end{array}$} & \multicolumn{4}{|c|}{ 5-YSR (\%) [3-YSR (\%)], RR } \\
\hline & & & & & & & & & & $\begin{array}{l}\text { Sublober/ } \\
\text { wedge }\end{array}$ & Seg & Lob & $\boldsymbol{P}$ \\
\hline Griffin et al. ${ }^{[10]}$ & 2006 & 31 & $\begin{array}{l}\text { Mean } \\
69\end{array}$ & NA & NA & Wedge & NA & NA & NA & (35) & NA & (35) & 0.8 \\
\hline Yendamuri et al. ${ }^{[11]}$ & 2007 & 68 & NA & NA & NA & Wedge & NA & $0(0)$ & NA & $(58)$ & NA & NA & 0.08 \\
\hline \multirow[t]{3}{*}{ Kraev et al. ${ }^{[12]}$} & 2007 & 74 & NA & $31(42)$ & NA & Wedge & NA & NA & NA & (37) & NA & $(52)$ & 0.1 \\
\hline & & & & & & $\mathrm{T}>3 \mathrm{~cm}$ & & & & (35) & NA & (35) & 0.9 \\
\hline & & & & & & $\mathrm{T}<3 \mathrm{~cm}$ & & & & (35) & NA & $(60)$ & 0.01 \\
\hline \multirow[t]{3}{*}{ El-Sherif et al. ${ }^{[14]}$} & 2007 & 81 & $\begin{array}{l}\text { Mean } \\
70\end{array}$ & NA & NA & $\begin{array}{l}\text { Sublober } \\
\text { (wedge } \\
55 ; 68 \% \text { ) }\end{array}$ & NA & $0(0)$ & $6(7)$ & NA (RFS) & NA & NA & NA \\
\hline & & 40 & & & & $M D>1$ & & $0(0)$ & $3(8)$ & (35) [80] & NA & NA & 0.2 \\
\hline & & 41 & & & & $\mathrm{MD}<1$ & & $0(0)$ & $6(15)$ & (58) [78] & NA & NA & $(0.7)$ \\
\hline Grills et al. ${ }^{[13]}$ & 2010 & 69 & $0(0 \%)$ & NA & NA & Wedge & NA & $0(0)$ & $20(29)$ & (52) [79] & NA & NA & 0.01 \\
\hline Wisnivesky et al..$^{[15]}$ & 2010 & 196 & $\begin{array}{l}>75 \\
(62 \%)\end{array}$ & $196(100)$ & NA & Sublober & NA & NA & NA & 1.1 & NA & Ref & $\begin{array}{c}\text { NS } \\
\text { (Cox) }\end{array}$ \\
\hline
\end{tabular}

NSCLC: non-small cell lung cancer; GGO: ground glass opacity; OP: operation; YSR: year survival rate; RR: relative risk; NA: not assessed or not available; MD: margin distance; RFS: relapse free survival rate; NS: not significant; Seg: segmentectomy; Lob: lobectomy; Ref: reference

in size $(P=0.029)$. They concluded that tumor size appears to be an important factor to be considered in preoperative planning. ${ }^{[12]}$ Based on these findings, the authors recommended randomized trials to confirm the superiority of lobectomy over wedge resection for stage IA lung cancers. ${ }^{[12]}$ The implications of tumor distance from surgical margin (margin-distance) in mini-invasive surgery have also been addressed. El-Sherif et al. ${ }^{[14]}$ demonstrated that margin-distance had a significant impact on local recurrences. In their report, $14.6 \%$ (6/41) of the patients with margin-distances of less than $1 \mathrm{~cm}$ developed local recurrences compared to $7.5 \%(3 / 40)$ of patients with margin-distances equal to or greater than $1 \mathrm{~cm}(P=0.04)$. Segmentectomy was the choice of surgery for $17 \%(7 / 41)$ and $47.5 \%(19 / 40)$ of the patients with margin-distances of less than $1 \mathrm{~cm}$ and equal to or greater than $1 \mathrm{~cm}$, respectively. The authors concluded that margin-distance was an important consideration after sublobar resection of NSCLC, because wedge resection was frequently associated with margins less than $1 \mathrm{~cm}$ and a high-risk for loco-regional recurrence. ${ }^{[14]}$ Although the clinical implications of tumor size and margin-distance were evaluated, margin cytology and ground glass opacity (GGO) did not receive much attention in the 2000s.

Investigations published in the 2010 s are summarized in Table 2. The mortality rate was also very low during this period, with a 5 -YSR of $55-65 \%$ (median, $61 \%$ ) for all ages ${ }^{[16-20]}$ and $41 \%$ for aged patients. ${ }^{[21]}$ The 5 -YSR seems to have improved in the 2010s, and this may be because the detection rate of small stage I tumors had increased for every decade as shown in the report from the Japanese Joint Committee of Lung Cancer Registry. ${ }^{[22]}$

The status of surgical margin of wedge resected clinical stage I NSCLC and patient outcomes has often been a consideration in the 2010s. This critical observation may have led to the designation of "occult margin malignancy" (malignant positive cytological surgical margin without histological positive result), which was introduced by Sawabata et al. ${ }^{[23]}$ This "occult margin malignancy" occurs not only in wedge resections, but also in segmentectomies and lobectomies. ${ }^{[24]}$ Furthermore, it had been revealed that insufficient margin-distance correlated with positive margin cytology results. ${ }^{[25]}$ Therefore, in order to achieve clean surgical margins (negative for malignancy) recent wedge resection may be carried out with sufficient margin-distance. Sawabata et al. ${ }^{[17]}$ reported that both $M / T$ and margin cytology findings were indicators of cancer recurrence and survival. In their series, all seven cases of surgical margin recurrences were associated with positive margin cytology results. Additionally, the 5-year survival rate was $54.2 \%(n=24)$ for $\mathrm{M} / \mathrm{T}$ less than 1 , and $84.6 \%$ for $\mathrm{M} / \mathrm{T}$ more than $1(n=13, P=$ $0.05)$, while it was $38.5 \%$ for positive margins $(n=13)$ and $79.2 \%$ for negative margins $(n=24, P=0.001)$. The authors therefore concluded that a pulmonary wedge resection for peripheral NSCLC should result in a negative malignant margin, which might be achieved with an M/T of more than 1. However, Maurizi et al. ${ }^{[26]}$ reported that among 243 consecutive patients with a functional contraindication to major lung resection, and who therefore underwent wedge resection with systematic lymph node (LN) dissection for clinical stage I NSCLC, loco-regional (lung parenchyma, hilum, mediastinum) recurrence rate was $26.4 \%$ $(n=48)$, distant recurrence rate was $11 \%(n=20)$, 5-YSR was $70.4 \%$, and 5-year disease-free survival (DFS) rate was $51.7 \%$. When the first 3 groups were compared, there was no statistically significant difference in loco-regional recurrence $(P=0.9)$, distant 
Table 2: Retrospective institutional study of pulmonary wedge resection for clinical stage I NSCLC after 2011

\begin{tabular}{|c|c|c|c|c|c|c|c|c|c|c|c|c|c|}
\hline \multirow{2}{*}{ Author } & \multirow[b]{2}{*}{ Year } & \multirow[b]{2}{*}{$n$} & \multirow[b]{2}{*}{$\begin{array}{l}\text { Age, } \\
\text { years }\end{array}$} & \multirow{2}{*}{$\begin{array}{c}\text { T1a }<2 \mathrm{~cm} \\
n(\%)\end{array}$} & \multirow{2}{*}{$\underset{n(\%)}{\text { GGO dominant, }}$} & \multirow[b]{2}{*}{ OP } & \multirow{2}{*}{$\begin{array}{c}\text { Margin } \\
\text { positive, } \\
n(\%)\end{array}$} & \multirow{2}{*}{$\begin{array}{c}\text { Mortality, } \\
n(\%)\end{array}$} & \multirow{2}{*}{$\begin{array}{c}\text { Local } \\
\text { relapse, } \\
n(\%)\end{array}$} & \multicolumn{4}{|c|}{ 5-YSR (\%) \{4-YSR (\%)\}, RR } \\
\hline & & & & & & & & & & $\begin{array}{c}\text { Sublober/ } \\
\text { wedge }\end{array}$ & Seg & Lob & $\boldsymbol{P}$ \\
\hline Nakamura et al. ${ }^{[16]}$ & 2011 & 84 & NA & NA & $28(33)$ & Wedge & NA & $0(0)$ & NA & (55) & $(82)$ & $(87)$ & NA \\
\hline \multirow[t]{5}{*}{ Sawabata et al. ${ }^{[17]}$} & 2012 & 37 & & $25(67)$ & NA & Wedge & $13(35)$ & $0(0)$ & $9(23)$ & (64) & NA & NA & \\
\hline & & 24 & & & & MNMC & $0(0)$ & & $0(0)$ & (79) & NA & NA & 0.01 \\
\hline & & 13 & & & & MPMC & $13(100)$ & & $8(62)$ & (39) & NA & NA & \\
\hline & & 13 & & & & $\mathrm{MD} / \mathrm{TS}>1$ & $0(0)$ & & $0(0)$ & (85) & NA & NA & 0.05 \\
\hline & & 24 & & & & $\mathrm{MD} / \mathrm{TS}<1$ & $12(50)$ & & $8(33)$ & (54) & NA & NA & \\
\hline Matsuo et al. ${ }^{[18]}$ & 2014 & 65 & Median 65 & NA & NA & Sublober & NA & $0(0)$ & & (61) & NA & NA & NA \\
\hline Mediratta et al. ${ }^{[19]}$ & 2014 & 540 & Median 72 & NA & NA & Wedge & NA & NA & NA & (65) & NA & NA & NA \\
\hline \multirow[t]{5}{*}{ Mohiuddin et al. ${ }^{[27]}$} & 2014 & 479 & $>80(10 \%)$ & $118(25)$ & NA & Wedge & NA & $1(0)$ & NA & (RFS) & & & \\
\hline & & 169 & & & & $\mathrm{MD}<0.5 \mathrm{~cm}$ & & & & $\{63\}$ & & & 0.03 \\
\hline & & 123 & & & & $\begin{array}{c}0.5 \mathrm{~cm}<\mathrm{MD} \\
\quad<1.0 \mathrm{~cm}\end{array}$ & & & & $\{70\}$ & & & \\
\hline & & NA & & & & $\begin{array}{c}1.0 \mathrm{~cm}<\mathrm{MD} \\
<1.5 \mathrm{~cm}\end{array}$ & & & & $\{80\}$ & & & \\
\hline & & NA & & & & $1.5 \mathrm{~cm}<\mathrm{MD}$ & & & & $\{82\}$ & & & \\
\hline Ambrogi et al. ${ }^{[20]}$ & 2015 & 59 & Median 70 & NA & NA & Wedge & NA & $0(0)$ & NA & (55) & NA & NA & NA \\
\hline \multirow[t]{4}{*}{ Maurizi et al..$^{[26]}$} & 2015 & 182 & Mean 70 & $138(76)$ & NA & Wedge & NA & $2(1)$ & $48(26)$ & NA & NA & NA & \\
\hline & & 30 & & 24 & & $\mathrm{MD}<1 \mathrm{~cm}$ & & & & (47) & NA & NA & NS \\
\hline & & 80 & & 63 & & $\begin{array}{c}1 \mathrm{~cm}<\mathrm{MD}< \\
2 \mathrm{~cm}\end{array}$ & & & & (54) & NA & NA & \\
\hline & & 72 & & 51 & & $2 \mathrm{~cm}<\mathrm{MD}$ & & & & (58) & NA & NA & \\
\hline Fiorelli et al. ${ }^{[21]}$ & 2016 & 90 & > 75 (100\%) & $40(44)$ & $1(2)$ & Sublober & NA & $0(0)$ & $12(13)$ & (41) & NA & (61) & 0.1 \\
\hline \multirow[t]{3}{*}{ Altorki et al. ${ }^{[28]}$} & 2016 & 160 & Median 74 & $136(85)$ & $22(14)$ & Wedge & $2(1)$ & $0(0)$ & $15(9)$ & Ref & 1.1 & & $\begin{array}{l}0.7 \\
\text { (Cox) }\end{array}$ \\
\hline & & 58 & & & & $\mathrm{MD} / \mathrm{TS}>1$ & NA & & & & & & \\
\hline & & 84 & & & & $\mathrm{MD} / \mathrm{TS}<1$ & NA & & & & & & \\
\hline \multirow[t]{3}{*}{ Stiles et al. ${ }^{[36]}$} & 2016 & 166 & Median 72 & $159(95)$ & $27(16)$ & Wedge & NA & $0(0)$ & $16(10)$ & NA & NA & NA & \\
\hline & & 138 & Median 72 & $111(80)$ & $20(14)$ & LNs & NA & $0(0)$ & $8(7)$ & (83) & NA & NA & 0.04 \\
\hline & & 58 & Median 72 & $48(83)$ & $7(12)$ & NLNs & NA & $0(0)$ & $8(7)$ & (56) & NA & NA & \\
\hline \multirow[t]{5}{*}{ Moon et al. ${ }^{[41]}$} & 2017 & 91 & & $67(74)$ & $52(57)$ & $\begin{array}{c}\text { Sublober } \\
\text { (wedge 63; } \\
69 \% \text { ) }\end{array}$ & NA & $0(0)$ & NA & (RFS) & & & \\
\hline & & 14 & Mean 66 & 13 & 14 & $\mathrm{MD}<0.5 \mathrm{~cm}$ & NA & & $0(0)$ & (100) & & & \\
\hline & & 38 & Mean 61 & 35 & 38 & $\mathrm{MD}>0.5 \mathrm{~cm}$ & NA & & $0(0)$ & (100) & & & \\
\hline & & 11 & Mean 71 & 6 & & $\mathrm{MD}<0.5 \mathrm{~cm}$ & NA & & & (24) & & & $<0.001$ \\
\hline & & 28 & Mean 69 & 23 & & $\mathrm{MD}>0.5 \mathrm{~cm}$ & NA & & & (80) & & & \\
\hline
\end{tabular}

NSCLC: non-small cell lung cancer; OP: operation; GGO: ground glass opacity; YSR: year survival rate; RR: relative risk; NA: not assessed or not available; RFS: relapse free survival rate; MNMC: malignant negative margin cytology; MPNC: malignant positive margin cytology; MD: margin distance; TS: tumor size; Ref: reference; NS: not significant; Seg: segmentectomy; Lob: lobectomy

recurrence $(P=0.3)$, and overall survival $(P=0.07)$ rates. It was therefore concluded that wedge resection is a viable option for the surgical treatment of stage I NSCLC when lobectomy is contraindicated, while the distance between the tumor and the parenchymal suture margin does not influence recurrence or the survival rate when an Ro resection is achieved. ${ }^{[26]}$ In contrast, Mohiuddin et al. ${ }^{[27]}$ after reviewing 497 non-biased adult patients who had undergone wedge resections for small (less than $2 \mathrm{~cm}$ ) NSCLC reported that the overall unadjusted 1 and 2 year local recurrence rates were $5.7 \%$ and $11.0 \%$, respectively. However, from the adjusted analyses, an increased margin-distance was significantly associated with a lower risk of local recurrence $(P=0.033)$, and patients with a $10 \mathrm{~mm}$ margin-distances had a $45 \%$ lower local recurrence risk than those with a $5 \mathrm{~mm}$ distance [hazard ratio (HR) $0.55,95 \%$ confidence interval (Cl): 0.35-0.86], while beyond $15 \mathrm{~mm}$, no evidence of additional benefit was achieved. It was therefore concluded that in wedge resection for small NSCLC, increasing the margin distance $15 \mathrm{~mm}$ significantly decreased the local recurrence risk, with no evidence of additional benefit beyond $15 \mathrm{~mm} \cdot{ }^{[27]}$ However, both Maurizi et al. ${ }^{[26]}$ and Mohiuddin et al. ${ }^{[27]}$ did not consider surgical margin cytology in their studies.

In view of the clinical implications of surgical margin cytology and distance, Altorki et al..[28] compared the outcomes of pulmonary wedge resection to segmentectomy for peripheral small sized lung cancers by examining both parameters. With a median follow-up of 34 months, there was no difference between patients who underwent wedge resection and anatomical segmentectomy in regards to local recurrence $(9 \%$ vs. $11 \% ; P=0.68)$ and 5 -year DFS $(51 \%$ vs. $53 \%$; $P=0.7)$. On the other hand, Smith et al. ${ }^{[29]}$ reported inferior survival outcome for wedge resection to segmentectomy using registry data. Analyses with adjustment for propensity scores of 3,525 patients 
Table 3: Retrospective study of pulmonary wedge resection for clinical stage I NSCLC using registry data

\begin{tabular}{|c|c|c|c|c|c|c|c|c|c|c|c|c|c|}
\hline \multirow[b]{2}{*}{ Author } & \multirow[b]{2}{*}{ Year } & \multirow[b]{2}{*}{$n$} & \multirow{2}{*}{$\begin{array}{l}\text { Age, } \\
\text { years }\end{array}$} & \multirow{2}{*}{$\begin{array}{c}\mathrm{T} 1 \mathrm{a}<2 \mathrm{~cm} \\
n(\%)\end{array}$} & \multirow{2}{*}{$\begin{array}{c}\text { GGO } \\
\text { dominant, } \\
n(\%)\end{array}$} & \multirow[b]{2}{*}{ OP } & \multirow{2}{*}{$\begin{array}{c}\text { Margin } \\
\text { positive }\end{array}$} & \multirow[b]{2}{*}{ Mortality } & \multirow{2}{*}{$\begin{array}{l}\text { Local } \\
\text { relapse }\end{array}$} & \multicolumn{4}{|c|}{ 5-YSR (\%) \{4-YSR (\%)\}, RR } \\
\hline & & & & & & & & & & $\begin{array}{c}\text { Sublober/ } \\
\text { wedge }\end{array}$ & Seg & Lob & $\boldsymbol{P}$ \\
\hline \multirow[t]{4}{*}{ Mery et al. ${ }^{[35]}$} & 2005 & 1,403 & NA & NA & NA & Wedge & NA & NA & NA & NA & NA & NA & \\
\hline & & NA & $<60$ & & & & & & & $(50)$ & NA & $(67)$ & 0.03 \\
\hline & & NA & $60-75$ & & & & & & & $(40)$ & NA & (54) & 0.0009 \\
\hline & & NA & $>75$ & & & & & & & (32) & NA & (39) & 0.5 \\
\hline Kates et al. ${ }^{[30]}$ & 2011 & 688 & $>70(43 \%)$ & $\begin{array}{c}688(100) \\
(<1 \mathrm{~cm})\end{array}$ & NA & Sublober & NA & NA & NA & 1.1 & NA & Ref & $\begin{array}{c}\text { NS } \\
\text { (Cox) }\end{array}$ \\
\hline Witson et al. ${ }^{[32]}$ & 2012 & 768 & $>80(12 \%)$ & $407(53)$ & NA & Wedge & NA & NA & NA & $(47)$ & $(69)$ & $(68)$ & $<0.001$ \\
\hline \multirow[t]{2}{*}{ Yendamuri et al. ${ }^{[31]}$} & 2013 & $\begin{array}{c}361 \\
(1998- \\
2004)\end{array}$ & NA & $361(100)$ & $61(17)$ & Wedge & NA & NA & NA & $\{50\}$ & $\{60\}$ & $\{75\}$ & $\begin{array}{l}<0.05 \\
\text { (wedge } \\
\text { vs. Lob) }\end{array}$ \\
\hline & & $\begin{array}{l}737 \\
(2005- \\
2008)\end{array}$ & NA & 737 (100) & $115(16)$ & Wedge & NA & NA & NA & $\{64\}$ & $\{73\}$ & $\{80\}$ & NS \\
\hline Smith et al. ${ }^{[29]}$ & 2013 & 1,568 & Mean 70 & $\begin{array}{c}\text { Mean size } \\
1.82 \mathrm{~cm}\end{array}$ & $\begin{array}{c}187(12) \\
\text { (pure) }\end{array}$ & Wedge & NA & NA & NA & Ref & 0.8 & NA & $\begin{array}{l}<0.05 \\
\text { (Cox) }\end{array}$ \\
\hline Warwick et al. ${ }^{[33]}$ & 2013 & 210 & Median 72 & NA & NA & Wedge & NA & NA & NA & (45) & NA & $(68)$ & 0.003 \\
\hline Khullar et al. ${ }^{[34]}$ & 2015 & 7,297 & Mean 68.9 & NA & NA & Wedge & $292(4 \%)$ & $11(2 \%)$ & NA & (54) & (58) & (71) & $\begin{array}{l}<0.001 \\
\text { (wedge } \\
\text { vs. Lob) }\end{array}$ \\
\hline
\end{tabular}

NSCLC: non-small cell lung cancer; OP: operation; GGO: ground glass opacity; YSR: year survival rate; RR: relative risk; NA: not assessed or not available; RFS: relapse free survival rate; Ref: reference; NS: not significant; Seg: segmentectomy; Lob: lobectomy

from the Surveillance, Epidemiology and End Results (SEER) registry revealed that, segmentectomy was associated with significant improvement in overall survival (HR 0.80, 95\% Cl: 0.69-0.93) and lung cancerspecific survival (HR 0.72, 95\% Cl: 0.59-0.88) compared to wedge resection. Thus, it was concluded that these results suggest that segmentectomy should be the preferred technique for limited resection of patients with stage IA NSCLC. ${ }^{[29]}$ However, margin status of wedge resection was not registered in the SEER registry.

In addition, it is reported that survival outcome of pulmonary wedge resection is similar to lobectomy for patients with tumors of less than $2.0 \mathrm{~cm} \cdot{ }^{[30,31]}$ The registry data shows that demonstrate inferior ${ }^{[29,32-34]}$ or non-inferior ${ }^{[30,31]}$ survival outcomes of pulmonary wedge resection to lobectomy [Table 3]. Furthermore, there is a report showing that the outcome of surgery was age-dependent. ${ }^{[35]}$

Lymph node (LN) dissection is also worthy of consideration because this is a standard procedure performed during lobectomy. However, because of potential side effects, caution should be exercised in choosing to perform this procedure. Stiles et al. ${ }^{[36]}$ evaluated all patients undergoing wedge resection for peripheral clinical stage IA NSCLC, and grouped them into those with and without $L N$ dissection. Of 196 patients undergoing wedge resection, of whom 138 $(70 \%)$ had LNs (median $=4$ nodes) resected and the remainder did not, there were no significant differences in the clinical or pathologic characteristics between the two groups. Additionally, no difference in terms of operating room time, estimated blood loss, chest tube duration or length of hospital stay was uncovered. However, the LN dissected group had higher probability of freedom from loco-regional recurrence compared to the no lymph node (NLN) group (5-year: $92 \%$ vs. $74 \%$, $P=0.025)$ and higher probability of freedom from local recurrence $(P=0.024)$ in propensity matched groups. The conclusion therefore was that LN removal appears to decrease loco-regional recurrence and may be associated with a survival benefit. ${ }^{[36]}$

\section{Intentional pulmonary sublobar resection for solid lesions}

As a standard practice, lung cancer patients with limited pulmonary function undergo limited resections, such as wedge resection or segmentectomy, which are referred to as "compromised resections". However, some surgeons prefer 'intentional' sublobar resections in patients with normal lung functions.

In 1997, Kodama et al. ${ }^{[37]}$ conducted a 10-year study of 63 patients who received limited resections (46 segmentectomies and 17 wedge resections) and 77 patients who underwent the standard operation (lobectomy plus complete mediastinal LN dissection) as curative-intent treatments for T1NOMO NSCLC. The 5-year survival rate was $93 \%$ in the intentional/ limited resection group, and this was not different from that of the 77 patients who underwent the standard operation. The frequency of local/regional recurrence in the intentional resection group was $8.7 \%(4 / 46)$, with mediastinal involvement in 3 patients. It was thus concluded that sublobar resection should be considered 
an acceptable alternative treatment for selected patients with T1N0M0 disease. Koike et al. ${ }^{[38]}$ studied 74 patients who received intentional limited resections for T1NOMO $(<2 \mathrm{~cm})$ disease, and uncovered that the calculated 3-year and 5-year survival rates were $94.0 \%$ and $89.1 \%$, respectively, which did not significantly differ from those of a lobectomy group. They therefore concluded that in patients with peripheral T1NOMO NSCLC whose maximum tumor diameter was $2 \mathrm{~cm}$ or less, the outcome of limited pulmonary resection is comparable with that of pulmonary lobectomy. Okada et al. ${ }^{[39]}$ also examined 260 sublobar resections, including 30 wedge resections, in comparison to 260 lobectomies, and found that DFS and overall survivals were similar in both groups. The 5 -year DFS and overall survival were $85.9 \%$ and $89.6 \%$, respectively for the sublobar resection group, and $83.4 \%$ and $89.1 \%$, respectively for the lobar resection group. The conclusion was that sublobar resection should be considered as an alternative for stage IA NSCLC 2 $\mathrm{cm}$ or less, even in low-risk patients. ${ }^{[39]}$ These results could lay the foundation for starting new randomized controlled trials, which could revolutionize lung cancer surgery in this era of early detection. In this context, a phase III randomized trial of lobectomy versus limited resection (segmentectomy) for small $(2 \mathrm{~cm}$ or less) peripheral NSCLC (JCOG0802/WJOG4607L) has been conducted in Japan.

\section{Pulmonary wedge resection for GGO predominant lesions}

In the 2010s, there was an increase in the number of articles that examined GGO lesions in regard to surgery. Asamura et al. ${ }^{[40]}$ conducted a prospective multi-institutional study whereby image diagnosis was used to define early (noninvasive) adenocarcinomas of the lung (Japan Clinical Oncology Group 0201). This study demonstrated that a consolidation/tumor ratio on thin-section computed tomography (CT) scans of 0.25 or less for cT1a (less than or equal to $2.0 \mathrm{~cm}$ ) lesions was a better radiologic criterion for early pathology than a ratio of 0.50 or less for T1a-b (less than or equal to $3.0 \mathrm{~cm}$ ) tumors. This criterion was used for prognostic evaluation of 545 patients with adenocarcinoma who underwent lobectomy and lymph node dissection. Using a consolidation/tumor ratio of 0.25 or less, the overall survival and 5-year relapsefree survival of the patients were $90.6 \%$ and $84.7 \%$, respectively. With a ratio 0.5 or less for $\mathrm{T} 1 \mathrm{a}-\mathrm{b}$ lesions, the 5-year overall survival for radiologic noninvasive (121 patients, $22.2 \%$ ) and invasive (424 patients, $77.8 \%$ ) adenocarcinomas was $96.7 \%$ and $88.9 \%$, respectively, and this difference was statistically significant $(P<0.001$, log-rank test). However, when a consolidation/tumor ratio of 0.25 or less for clinical T1a was used, the 5-year overall survival rates of radiologic noninvasive (35 patients, 12.1\%) and invasive (254 patients, $87.9 \%$ ) adenocarcinomas were $97.1 \%$ and $92.4 \%$, respectively, and the difference was not statistically significant. It is currently widely accepted that the radiologic criteria of a consolidation/tumor ratio of 0.25 or less in clinical T1a and 0.50 in clinical T1a-b are both able to define a homogeneous group of patients with an excellent prognosis before surgery.

Margin-distance is an indicator of recurrence among patients with solid but not GGO predominant lesions. In the study by Moon et al.,. ${ }^{[41]}$ there was no recurrence in GGO-predominant tumors after sublobar resection, and this was not influenced by margin-distance. However, for solid-predominant tumors, the 5-year recurrencefree survival after sublobar resection according to margin-distances of less than $5 \mathrm{~mm}$ and more than $5 \mathrm{~mm}$ were $24.2 \%$ and $79.6 \%$, respectively $(P=0.001)$. The conclusion therefore was as follows that the distance between the tumor and resection margin does not affect the recurrence after Ro sublobar resection in patients with clinical NO GGO-predominant lung cancer less than $3 \mathrm{~cm}$ but margin distance is a significant risk factor for recurrence after sublobar resection in patients with clinical NO solid-predominant lung cancer. ${ }^{[41]}$

\section{Stereotactic body radiation therapy}

Because conventional 2-dimentional radiation therapy of lung cancer has resulted in inadequate rates of local control and adverse effects, it is being replaced by SBRT, which is mainly administered for stage I lung cancer with acceptable morbidity and local control rates. ${ }^{[42,43]}$ Among inoperable patients, the mortality and severe morbidity from SBRT were few, and the 5-year survival rate was less than $20 \%(17-19 \%) .{ }^{[44-46]}$ Additionally, in non-biased patients with stage IA NSCLC, mortality and severe morbidity seldom occurred, but controllable radiation pneumonitis developed in up to $20 \%$ of the patients, and the median 5-year survival rate was 39\% (ranged, 30-73\%). ${ }^{[47-50]}$ It has also been reported that the outcome of surgery is superior to SBRT. ${ }^{[51-53]}$

\section{Comparison of pulmonary wedge resection and radiation therapy}

Clinical observational studies that compared the outcomes of pulmonary wedge resection to SBRT suggest SBRT is inferior ${ }^{[11,13,18]}$ but comparable to wedge/sublobar pulmonary resection among operable $^{[53]}$ and elderly ${ }^{[54]}$ patients.

\section{PROSPECTIVE CLINICAL STUDIES}

\section{Pulmonary wedge resection}

The Lung Cancer Study Group (LCSG) conducted the 
first multicenter prospective study in 1995 that compared wedge/sublobar pulmonary resection to lobectomy. ${ }^{[5]}$ In this study, the rate of local recurrence was $17 \%$ in patients who received wedge/sublobar resections (40 wedge resections) in contrast to $6 \%$ for the lobectomy group $(P=0.008)$. The 3 - and 5 -year survival rates of the wedge/sublobar resection group were $79 \%$ and $48 \%$, respectively. Although the survival rate was not statistically significant between the groups $(P=0.1)$, wedge/sublobar resection has not been accepted as a standard therapy for clinical stage I NSCLC.

A number of clinical trials have now been conducted to evaluate the usefulness of various surgical strategies for treating early sage lung cancer. Recently, a phase III randomized trial (JCOG0802/WJOG4607L) was conducted in Japan to evaluate the non-inferiority of overall survival of limited resection (segmentectomy) over lobectomy in patients with small peripheral NSCLC ( $2 \mathrm{~cm}$ or less, the proportion of maximum diameter of the tumor itself to consolidation > 0.5). ${ }^{[56]}$ In addition, a non-randomized confirmatory study (JCOG0804/ WJOG4507L) has been conducted to evaluate the efficacy and safety of limited resection (wedge resection in general) in patients with small ( $2 \mathrm{~cm}$ or less) peripheral radiological noninvasive lung cancer, diagnosed by preoperative thin-section CT scan images. ${ }^{[57]}$ Another confirmatory trial (JCOG1211) has been conducted to confirm the efficacy of limited resection (lung segmentectomy) in patients with GGO-predominant lung cancers of less than or equal to $3 \mathrm{~cm}$ in diameter based on thin-section CT scans. ${ }^{[58]}$ In South America, a randomized phase III trial has also been conducted to compare the efficacy of different types of surgeries used to treat patients with stage IANSCLC. ${ }^{[59]}$ Wedge resection or segmentectomy may be less invasive surgeries with fewer side effects and improve recovery than lobectomy for NSCLC, but it is not yet known whether wedge resection or segmentectomy are more effective than lobectomy in treating stage IA NSCLC. However, there have been only three completed multicenter prospective studies of pulmonary wedge resections, including the LCSG study. ${ }^{[55,60,61]}$

The American College of Surgeons Oncology Group (ACOSOG) completed a multicenter prospective study named Z4032.[60] The ACOSOG Z4032 was a randomized phase III trial comparing sublobar resection to sublobar resection plus brachytherapy (wire of I-125 implantation at the site of surgical margin) in patients with stage I NSCLC who were considered high-risk for lobectomy. The study was closed to accrual in January 2010 after a planned enrollment of 222 evaluable patients. Although the study failed to reveal the efficacy of $\mathrm{I}-125$ brachytherapy, its results are important reference data of pulmonary wedge/sublobar resection of NSCLC. The ASOCOG Z4032 results revealed a local control rate of $71 \%$ and a 3-year survival rate of $76 \%$ in the wedge/sublobar resection group. Although the local control rate was not different regardless of brachytherapy administration, it was higher among cases with cytological malignant positive surgical margins that receive I-125 brachytherapy. Thus I-125 brachytherapy was proven to be effective.

The Kanetsu Lung-cancer Study Group (KLSG) conducted a one arm multicenter prospective study (KLSG0801) to investigate the feasibility of wedge/ sublobar pulmonary resection among patients with limited cardio-pulmonary preservation in Japan. ${ }^{[61]}$ This study uncovered grade 3 morbidity in only 2 cases $(7 \%)$, a calculated 3 -year surgical margin control rate of $97 \%$, a calculated 3-year local recurrence control rate of $76 \%$, and a calculated 3 -year overall survival rate of $79 \%$, supporting the feasibility of wedge/sublobar pulmonary resection for NSCLC. In the KLSG0801 study, surgical margin cytology was carried out in $21(67 \%)$ and margin-distance was measured in all $(100 \%)$ cases. The calculated 3 -year overall survival rate was $88 \%$ for negative margin cytology in contrast to $20 \%$ for those with positive margins. This finding suggests the importance of determining surgical margin cytology during pulmonary wedge resection of NSCLC. Furthermore, $80 \%$ of cases that revealed malignant positive margin cytology possessed $\mathrm{M} / \mathrm{T}$ ratio of greater than 1 , which further emphasizes the importance of performing pulmonary wedge resection with sufficient parenchymal surgical margin-distance. The results of a prospective study of wedge/sublobar resection for clinical stage I NSCLC are summarized in Table 4.

\section{Stereotactic body radiation therapy}

A prospective multicenter study of SBRT demonstrated a 3-year recurrence-free survival rate of $48-80 \%$, 3-year overall survival rate of $56-90 \%$, and tumor control rate of $86-98 \%$ with acceptable rates of adverse effects [Table 5]. ${ }^{[62-64]}$ In addition, a recent prospective phase III study with SBRT and lobectomy arms suggests SBRT could be an option for treating operable stage I NSCLC; however, a limitation of this study was the small sample size. ${ }^{[64]}$

Besides, there are technical limitations associated with SBRT such as "no-fly-zone" and irradiation of hilar tumors, and complications such as pulmonary fibrosis and hemoptysis, which should be considered when comparing surgery to SBRT. In addition, patients with unknown histologic diagnosis received SBRT in most of the studies. 
Table 4: Prospective studies of pulmonary wedge/sublobar resection for clinical stage I NSCLC (\%)

\begin{tabular}{|c|c|c|c|c|c|c|c|c|c|c|c|c|c|c|c|c|}
\hline \multirow{3}{*}{ Study } & \multirow{3}{*}{ Year } & \multirow{3}{*}{$n$} & \multicolumn{2}{|c|}{ Operation } & \multicolumn{3}{|c|}{ Margin exploration } & \multicolumn{6}{|c|}{ 3-year recurrence free rate } & \multicolumn{3}{|c|}{ 3-year overall survival rate } \\
\hline & & & \multirow{2}{*}{ Seg } & \multirow{2}{*}{ Wed } & \multirow{2}{*}{ MD } & \multirow{2}{*}{ All } & \multirow{2}{*}{$M C(+)$} & \multicolumn{6}{|c|}{ Margin recurrence free Recurrence free } & \multirow{2}{*}{ All } & \multirow{2}{*}{$M C(+)$} & \multirow{2}{*}{$\mathrm{MC}(-)$} \\
\hline & & & & & & & & All & $\mathrm{MC}(+)$ & MC(-) & All & $M C(+)$ & MC(-) & & & \\
\hline $\operatorname{LCSG}^{[55]}$ & 1995 & 122 & 82 & 40 & NA & NA & NA & NA & NA & NA & 78 & NA & NA & 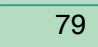 & NA & NA \\
\hline 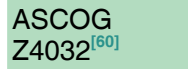 & 2014 & 222 & 47 & 155 & 100 & NA & 7 & NA & NA & NA & 71 & $<60$ & NA & 76 & $<70$ & NA \\
\hline KLSG $0801^{[61]}$ & 2016 & 32 & 1 & 31 & 100 & 67 & 16 & 97 & 80 & 100 & 76 & NA & NA & 79 & 20 & 88 \\
\hline
\end{tabular}

NSCLC: non-small cell lung cancer; NA: not assessed or not available; MD: margin distance; MC: margin cytology; (+): malignant positive; (-): malignant negative; Seg: segmentectomy; Wed: wedge

Table 5: Prospective studies of stereotactic body radiation therapy for clinical stage I NSCLC

\begin{tabular}{|c|c|c|c|c|c|c|c|c|c|c|}
\hline Study & Year & Design & Operability & $n$ & $\begin{array}{c}\text { Age } \\
\text { (median, } \\
\text { years) }\end{array}$ & $\begin{array}{c}\text { Tumor size } \\
\text { (median, cm) }\end{array}$ & $\begin{array}{c}\text { 3-year } \\
\text { recurrence } \\
\text { free rate (\%) }\end{array}$ & $\begin{array}{c}\text { 3-year overall } \\
\text { survival rate } \\
(\%)\end{array}$ & $\begin{array}{l}\text { Tumor } \\
\text { controal } \\
\text { rate (\%) }\end{array}$ & $\begin{array}{c}\text { Mortaliy } \\
(\%)\end{array}$ \\
\hline $\mathrm{RTOG0236}^{[62]}$ & 2010 & Phase II & In-operable & 55 & 72 & $\mathrm{~T} 1,2$ & 48 & 56 & 98 & 0 \\
\hline \multirow[t]{3}{*}{$\mathrm{JCOG} 0403^{[63]}$} & 2015 & Phase II & & 169 & & & & & & \\
\hline & & & Operable & 65 & 79 & 2.1 & 69 & 76 & 86 & 0 \\
\hline & & & In-operable & 104 & 78 & 2.1 & 50 & 60 & 88 & 0 \\
\hline \multirow{3}{*}{$\begin{array}{l}\text { STARS, } \\
\text { ROSEL }^{[64]}\end{array}$} & 2015 & Randomized & Operable & 58 & & & & & & \\
\hline & & & SBRT & 31 & 67 & NA & 86 & 95 & 96 & 0 \\
\hline & & & Surgery & 27 & 66 & NA & 80 & 79 & 100 & 0 \\
\hline
\end{tabular}

NSCLC: non-small cell lung cancer; SBRT: stereotactic body radiation therapy; NA: not assessed or not available

\section{Comparison of pulmonary wedge resection} and stereotactic body radiation therapy

Investigators from both ACOSOG and the Radiation Therapy Oncology Group (RTOG) embarked on a randomized phase III study of SBRT vs. pulmonary wedge resection for high-risk operable NSCLC patients (ACOSOGZ4099/RTOG1021) that opened for accrual in 2012. ${ }^{[65]}$ The ACOSOG Z4099 is a randomized phase III study that will compare sublobar resection (SR) and SBRT for high-risk operable NSCLC patients. Eligible patients will have clinical stage I disease with tumors of $3 \mathrm{~cm}$ or less in the maximum diameter. Invasive lymph node staging will not be mandatory for all patients. However, patients with clinically suspicious lymph nodes (defined as $>1 \mathrm{~cm}$ on the short axis by CT scan and/or positive by positron emission tomography) will require biopsy to confirm $\mathrm{NO}$ status before registration. Biopsy methods can include mediastinoscopy, anterior mediastinotomy, endoscopic ultrasonography, endobronchial ultrasonography, CT-guided techniques, and video-assisted thoracic surgical biopsy. It is possible that in the surgical arm of the study, the diseases of some patients will be upstaged. However, the primary analysis will be an "intent-to-treat" analysis, and all patients registered and randomized will be included in that analysis. Tumors will have to be in locations that will permit sublobar resection, and also not within $2 \mathrm{~cm}$ of the proximal bronchial tree in all directions. Tumors in close proximity to the bronchial tree have previously been demonstrated to have a high incidence of grade 4 and 5 toxicity with standard-dose SBRT. ${ }^{[66]}$ Additionally, tissue diagnosis confirming NSCLC will be required for all patients before registration. Eligible patients will be defined as high-risk using the ACOSOG Z4032 criteria. ${ }^{[60]}$ The ACOSOG Z4032 was a randomized study undertaken to compare wedge/sublobar resection alone to wedge/sublobar resection plus brachytherapy for stage I lung cancer. Although closed to accrual, the primary endpoint data was not yet available at the time ACOSOG Z4099 opened. Brachytherapy is not a requirement in the surgical arm of ACOSOG Z4099, and the decision to use brachytherapy will be determined by institutional preference. The primary endpoint for the study will be 3-year overall survival. The secondary endpoint will include comparisons of loco-regional recurrence (using a uniform definition), DFS, grade 3 or higher adverse effects during a 1-year period, the effect of therapy on pulmonary function, and adverse effects and pulmonary function test results in patients with high or low Charlson comorbidity index scores. In addition, some correlative studies will be undertaken to consider patients' quality of life, as well as molecular studies using tissue and blood samples. The target accrual for ACOSOG Z4099 is 420 patients. Unfortunately this study seems to have been closed due to very slow patient accrual.

\section{COMMENTS}

The outcome data of clinical studies of pulmonary wedge/sublobar resection and/or SBRT were not different, and both had acceptable morbidity and 
mortality rates. However, technical limitations and complications associated with SBRT, including "no-flyzone", irradiation of hilar tumors, pulmonary fibrosis, and hemoptysis should be considered when comparing surgery to SBRT. Moreover, in many studies, patients with unknown histologic diagnosis received SBRT. However, in order to perform SBRT, the lesion should be diagnosed cytologically and/or pathologically. Because diagnosing a cancer lesion involves some interventions, it is necessary to consider the merits and demerits of each diagnostic procedure.

There are three main methods used to diagnose lung cancer are transbronchial biopsy with flexible fibertopic bronchoscopy (FFB), CT-guided fine needle aspiration biopsy (FNAC), and surgical resection. ${ }^{[67]}$ Each method is important but has some drawbacks. FNAC has potential to disseminate cancer cells through the needle tract. ${ }^{[68]}$ In a clinical settings, it has been reported that the relapse rate due to pleural recurrences is higher in FNAC than other diagnostic methods. ${ }^{[69,70]}$ There are also reports that reveal a prognostic disadvantage of biopsy using FFB. ${ }^{[71,72]}$ Pulmonary wedge resection is also a useful diagnostic technique for pulmonary nodules suspicious of malignancy, in addition to complete lesion resection with sufficient margin. As such, wedge/sublobar resection may be more suitable than SBRT in operable patients with no pathological diagnosis, and a select group of patients even if the cytological and/or pathological diagnosis is attained. In addition, if surgeons decide to carry out sampling of suspicious lymph nodes as in ACOSOG Z4032, knowledge of lymph node metastasis can inform adjuvant therapy. ${ }^{[60]}$

Even if the results of ACOSOGZ4099/RTOG1201 is affirmative for SBRT, it would be important for selecting a subgroup of patients for wedge/sublobar resection based on tumor size, location, margin-distance, M/T ratio, and margin cytology. In addition, it has been reported that pure GGO and mixed GGO lesions are different from pure solid lesions in regards to surgical and radiation therapies. ${ }^{[40,73,74]}$ Therefore the proportion of GGO in a tumor is a very important parameter for choosing a treatment method. The International LungClinical-Study Organization/Kanetsu Lung Cancer Study Group therefore embarked on a multicenter prospective study of wedge pulmonary resection for clinical stage I NSCLC (ILO1502/KLSG1602, UMIN000024303) that opened in October 2016, with mandatory assessment of GGO, resection type, tumor location, tumor size, margin-distance, $M / T$ ratio, and margin cytology with the primary end-point of local control. ${ }^{[75]}$

In conclusion: (1) patient survival after wedge/ sublobar resection of stage I NSCLC is improving, and is not significantly different globally for peripheral small-sized tumors; (2) there are phase III studies comparing lobectomy and segmentectomy but not wedge resection; (3) survival probability of wedge resection seems to be similar to that of SBRT, but SBRT has limitations such as "no-fly-zone", irradiation of hilar tumors and associated complications such as pulmonary fibrosis and hemoptysis; and (4) a suitable subgroup of patients for wedge/sublobar resection may be found based on tumor size, location, margindistance, $\mathrm{M} / \mathrm{T}$ ratio, and margin cytology.

\section{Authors' contributions}

Organizing this review and writing: N. Sawabata Making a discussion and comments on the context of this review: A. Kawase, N. Takahashi, T. Kawaguchi, N. Matsutani

\section{Financial support and sponsorship}

None.

\section{Conflicts of interest}

There are no conflicts of interest.

\section{Patient consent}

Not applicable.

\section{Ethics approval}

Not applicable.

\section{REFERENCES}

1. Masuda M, Kuwano H, Okumura M, Amano J, Arai H, Endo S, Doki Y, Kobayashi J, Motomura N, Nishida H, Saiki Y, Tanaka F, Tanemoto $\mathrm{K}$, Toh Y, Yokomise H. Thoracic and cardiovascular surgery in Japan during 2012: annual report by The Japanese Association for Thoracic Surgery. Gen Thorac Cardiovasc Surg 2014;62:734-64.

2. Goldstraw P, Chansky K, Crowley J, Rami-Porta R, Asamura H, Eberhardt WE, Nicholson AG, Groome P, Mitchell A, Bolejack V. The IASLC lung cancer staging project: proposals for revision of the TNM stage groupings in the forthcoming (eighth) edition of the TNM classification for lung cancer. J Thorac Oncol 2016;11:39-51.

3. Fernando HC, De Hoyos A, Landreneau RJ, Gilbert S, Gooding WE, Buenaventura PO, Christie NA, Belani C, Luketich JD. Radiofrequency ablation for the treatment of non-small cell lung cancer in marginal surgical candidates. $J$ Thorac Cardiovasc Surg 2005;129:639-44.

4. Ambrogi MC, Fanucchi O, Dini P, Melfi F, Davini F, Lucchi M, Massimetti G, Mussi A. Wedge resection and radiofrequency ablation for stage I nonsmall cell lung cancer. Eur Respir J 2015;45:1089-97.

5. Kawamura M, Izumi Y, Tsukada N, Asakura K, Sugiura H, Yashiro H, Nakano K, Nakatsuka S, Kuribayashi S, Kobayashi K. Percutaneous cryoablation of small pulmonary malignant tumors under computed tomographic guidance with local anesthesia for nonsurgical candidates. J Thorac Cardiovasc Surg 2006;131:1007-13.

6. Linden PA, D'Amico TA, Perry Y, Saha-Chaudhuri P, Sheng S, Kim 
S, Onaitis M. Quantifying the safety benefits of wedge resection: a society of thoracic surgery database propensity-matched analysis. Ann Thorac Surg 2014;98:1705-11.

7. Miller JI, Hatcher CR Jr. Limited resection of bronchogenic carcinoma in the patients with marked impairment of pulmonary function. Ann Thorac Surg 1987;44:340-3.

8. Errett LE, Wilson J, Chiu RC, Munro DD. Wedge resection as an alternative procedure for peripheral bronchogenic carcinoma in poorrisk patients. J Thorac Cardiovasc Surg 1985;90:656-61.

9. Landreneau RJ, Sugarbaker DJ, Mack MJ, Hazelrigg SR, Luketich JD, Fetterman L, Liptay MJ, Bartley S, Boley TM, Keenan RJ, Ferson PF, Weyant RJ, Naunheim KS. Wedge resection versus lobectomy for stage I (T1 N0 M0) non-small-cell lung cancer. J Thorac Cardiovasc Surg 1997;113:691-8.

10. Griffin JP, Eastridge CE, Tolley EA, Pate JW. Wedge resection for non-small cell lung cancer in patients with pulmonary insufficiency: prospective ten-year survival. J Thorac Oncol 2006;1:960-4.

11. Yendamuri S, Komaki RR, Correa AM, Allen P, Wynn B, Blackmon S, Hofstetter WL, Rice DC, Roth JA, Swisher SG, Vaporciyan AA, Walsh GL, Mehran RJ. Comparison of limited surgery and threedimensional conformal radiation in high-risk patients with stage I non-small cell lung cancer. $J$ Thorac Oncol 2007;2:1022-8.

12. Kraev A, Rassias D, Vetto J, Torosoff M, Ravichandran P, Clement C, Kadri A, Ilves R. Wedge resection vs. lobectomy: 10-year survival in stage I primary lung cancer. Chest 2007;131:136-40.

13. Grills IS, Mangona VS, Welsh R, Chmielewski G, McInerney E, Martin S, Wloch J, Ye H, Kestin LL. Outcomes after stereotactic lung radiotherapy or wedge resection for stage I non-small-cell lung cancer. J Clin Oncol 2010;28:928-35.

14. El-Sherif A, Fernando HC, Santos R, Pettiford B, Luketich JD, Close JM, Landreneau RJ. Margin and local recurrence after sublobar resection of non-small cell lung cancer. Ann Surg Oncol 2007; 14:2400-5.

15. Wisnivesky JP, Henschke CI, Swanson S, Yankelevitz DF, Zulueta J, Marcus S, Halm EA. Limited resection for the treatment of patients with stage IA lung cancer. Ann Surg 2010;251:550-4.

16. Nakamura H, Taniguchi Y, Miwa K, Adachi Y, Fujioka S, Haruki T, Takagi Y, Yurugi Y. Comparison of the surgical outcomes of thoracoscopic lobectomy, segmentectomy, and wedge resection for clinical stage I non-small cell lung cancer. Thorac Cardiovasc Surg 2011;59:137-41.

17. Sawabata N, Maeda H, Matsumura A, Ohta M, Okumura M. Clinical implications of the margin cytology findings and margin/tumor size ratio in patients who underwent pulmonary excision for peripheral non-small cell lung cancer. Surg Today 2012;42:238-44.

18. Matsuo Y, Chen F, Hamaji M, Kawaguchi A, Ueki N, Nagata Y, Sonobe M, Morita S, Date H, Hiraoka M. Comparison of longterm survival outcomes between stereotactic body radiotherapy and sublobar resection for stage I non-small-cell lung cancer in patients at high risk for lobectomy: a propensity score matching analysis. Eur $J$ Cancer 2014;50:2932-8.

19. Mediratta N, Shackcloth M, Page R, Woolley S, Asante-Siaw J, Poullis $\mathrm{M}$. Should males ever undergo wedge resection for stage 1 non-smallcell lung cancer? A propensity analysis. Eur J Cardiothorac Surg 2014; $46: 267-73$

20. Ambrogi MC, Fanucchi O, Dini P, Melfi F, Davini F, Lucchi M, Massimetti G, Mussi A. Wedge resection and radiofrequency ablation for stage I nonsmall cell lung cancer. Eur Respir J 2015;45:1089-97.

21. Fiorelli A, Caronia FP, Daddi N, Loizzi D, Ampollini L, Ardò N, Ventura L, Carbognani P, Potenza R, Ardissone F, Sollitto F, Mattioli S, Puma F, Santini M, Ragusa M. Sublobar resection versus lobectomy for stage I non-small cell lung cancer: an appropriate choice in elderly patients? Surg Today 2016;46:1370-82.
22. Sawabata N, Miyaoka E, Asamura H, Nakanishi Y, Eguchi K, Mori M, Nomori H, Fujii Y, Okumura M, Yokoi K; Japanese Joint Committee for Lung Cancer Registration. Japanese lung cancer registry study of 11,663 surgical cases in 2004: demographic and prognosis changes over decade. J Thorac Oncol 2011;6:1229-35.

23. Sawabata N, Matsumura A, Ohota M, Maeda H, Hirano H, Nakagawa K, Matsuda H; Thoracic Surgery Study Group of Osaka University. Cytologically malignant margins of wedge resected stage I non-small cell lung cancer. Ann Thorac Surg 2002;74:1953-7.

24. Sawabata N, Karube Y, Umezu H, Tamura M, Seki N, Ishihama H, Honma K, Miyoshi S. Cytologically malignant margin without continuous pulmonary tumor lesion: cases of wedge resection, segmentectomy and lobectomy. Interact Cardiovasc Thorac Surg 2008;7:1044-8.

25. Sawabata N, Ohta M, Matsumura A, Nakagawa K, Hirano H, Maeda H, Matsuda H; Thoracic Surgery Study Group of Osaka University. Optimal distance of malignant negative margin in excision of nonsmall cell lung cancer: a multicenter prospective study. Ann Thorac Surg 2004;77:415-20

26. Maurizi G, D’Andrilli A, Ciccone AM, Ibrahim M, Andreetti C, Tierno S, Poggi C, Menna C, Venuta F, Rendina EA. Margin distance does not influence recurrence and survival after wedge resection for lung cancer. Ann Thorac Surg 2015;100:918-24.

27. Mohiuddin K, Haneuse S, Sofer T, Gill R, Jaklitsch MT, Colson YL, Wee J, Bueno R, Mentzer SJ, Sugarbaker DJ, Swanson SJ. Relationship between margin distance and local recurrence among patients undergoing wedge resection for small $(\leq 2 \mathrm{~cm})$ non-small cell lung cancer. J Thorac Cardiovasc Surg 2014;147:1169-75.

28. Altorki NK, Kamel MK, Narula N, Ghaly G, Nasar A, Rahouma M Lee PC, Port JL, Stiles BM. Anatomical segmentectomy and wedge resections are associated with comparable outcomes for patients with small cT1N0 non-small cell lung cancer. J Thorac Oncol 2016;11:1984-92.

29. Smith CB, Swanson SJ, Mhango G, Wisnivesky JP. Survival after segmentectomy and wedge resection in stage I non-small-cell lung cancer. J Thorac Oncol 2013;8:73-8.

30. Kates M, Swanson S, Wisnivesky JP. Survival following lobectomy and limited resection for the treatment of stage I non-small cell lung cancer $\leq 1 \mathrm{~cm}$ in size: a review of SEER data. Chest 2011;139:491-6.

31. Yendamuri S, Sharma R, Demmy M, Groman A, Hennon M, Dexter E, Nwogu C, Miller A, Demmy T. Temporal trends in outcomes following sublobar and lobar resections for small $(\leq 2 \mathrm{~cm})$ non-small cell lung cancers--a Surveillance Epidemiology End Results database analysis. J Surg Res 2013;183:27-32.

32. Whitson BA, Groth SS, Andrade RS, Mitiek MO, Maddaus MA, D'Cunha J. Invasive adenocarcinoma with bronchoalveolar features: a population-based evaluation of the extent of resection in bronchoalveolar cell carcinoma. J Thorac Cardiovasc Surg 2012;143:591-600.

33. Warwick R, Mediratta N, Shackcloth M, Page R, McShane J, Shaw M, Poullis M. Wedge resection verses lobectomy for stage 1 non-smallcell lung cancer. Asian Cardiovasc Thorac Ann 2013;21:566-73.

34. Khullar OV, Liu Y, Gillespie T, Higgins KA, Ramalingam S, Lipscomb J, Fernandez FG. Survival after sublobar resection versus lobectomy for clinical stage IA lung cancer: an analysis from the National Cancer Data Base. J Thorac Oncol 2015;10:1625-33.

35. Mery CM, Pappas AN, Bueno R, Colson YL, Linden P, Sugarbaker DJ, Jaklitsch MT. Similar long-term survival of elderly patients with non-small cell lung cancer treated with lobectomy or wedge resection within the surveillance, epidemiology, and end results database. Chest 2005;128:237-45

36. Stiles BM, Kamel MK, Nasar A, Harrison S, Nguyen AB, Lee P, Port JL, Altorki NK. The importance of lymph node dissection 
accompanying wedge resection for clinical stage IA lung cancer $\uparrow$. Eur J Cardiothorac Surg 2017;51:511-7.

37. Kodama K, Doi O, Higashiyama M, Yokouchi H. Intentional limited resection for selected patients with T1 N0 M0 non-small-cell lung cancer: a single-institution study. J Thorac Cardiovasc Surg 1997;114:347-53.

38. Koike T, Yamato Y, Yoshiya K, Shimoyama T, Suzuki R. Intentional limited pulmonary resection for peripheral T1 N0 M0 small-sized lung cancer. J Thorac Cardiovasc Surg 2003;125:924-8.

39. Okada M, Koike T, Higashiyama M, Yamato Y, Kodama K, Tsubota N. Radical sublobar resection for small-sized non-small cell lung cancer: a multicenter study. J Thorac Cardiovasc Surg 2006;132:76975 .

40. Asamura H, Hishida T, Suzuki K, Koike T, Nakamura K, Kusumoto M, Nagai K, Tada H, Mitsudomi T, Tsuboi M, Shibata T, Fukuda H; Japan Clinical Oncology Group Lung Cancer Surgical Study Group. Radiographically determined noninvasive adenocarcinoma of the lung: survival outcomes of Japan Clinical Oncology Group 0201. J Thorac Cardiovasc Surg 2013;146:24-30.

41. Moon Y, Lee KY, Moon SW, Park JK. Sublobar resection margin width does not affect recurrence of clinical N0 non-small cell lung cancer presenting as GGO-predominant nodule of $3 \mathrm{~cm}$ or less. World J Surg 2017;41:472-9.

42. Sirzén F, Kjellén E, Sörenson S, Cavallin-Ståhl E. A systematic overview of radiation therapy effects in non-small cell lung cancer. Acta Oncol 2003;42:493-515.

43. Onishi H, Araki T, Shirato H, Nagata Y, Hiraoka M, Gomi K, Yamashita T, Niibe Y, Karasawa K, Hayakawa K, Takai Y, Kimura T, Hirokawa Y, Takeda A, Ouchi A, Hareyama M, Kokubo M, Hara R, Itami J, Yamada K. Stereotactic hypofractionated high-dose irradiation for stage I nonsmall cell lung carcinoma: clinical outcomes in 245 subjects in a Japanese multiinstitutional study. Cancer 2004;101:1623-31.

44. Davis JN, Medbery C 3rd, Sharma S, Perry D, Pablo J, D'Ambrosio DJ, McKellar H, Kimsey FC, Chomiak PN, Mahadevan A. Stereotactic body radiotherapy for early-stage non-small cell lung cancer: clinical outcomes from a National Patient Registry. J Radiat Oncol 2015;4:5563.

45. Shibamoto Y, Hashizume C, Baba F, Ayakawa S, Miyakawa A, Murai T, Takaoka T, Hattori Y, Asai R. Stereotactic body radiotherapy using a radiobiology-based regimen for stage I non-small-cell lung cancer: five-year mature results. J Thorac Oncol 2015;10:960-4.

46. Hamaji M, Chen F, Matsuo Y, Kawaguchi A, Morita S, Ueki N, Sonobe M, Nagata Y, Hiraoka M, Date H. Video-assisted thoracoscopic lobectomy versus stereotactic radiotherapy for stage I lung cancer. Ann Thorac Surg 2015;99:1122-9.

47. Bhandari RP, Stanford JD, Packianathan S, Duggar WN, Kanakamedala MR, Zhang X, Giri SP, Kumar PP, Harrell LM, Mangana SH, Yang C, Vijayakumar S. Stereotactic body radiation therapy for stage I non-small cell lung cancer: a retrospective, singlecenter study of 55 patients. Oncology 2016;91:194-204.

48. Lischalk JW, Woo SM, Kataria S, Aghdam N, Paydar I, Repka MC, Anderson ED, Collins BT. Long-term outcomes of stereotactic body radiation therapy (SBRT) with fiducial tracking for inoperable stage I non-small cell lung cancer (NSCLC). J Radiat Oncol 2016;5:379-87.

49. Puri V, Crabtree TD, Bell JM, Broderick SR, Morgensztern D, Colditz GA, Kreisel D, Krupnick AS, Patterson GA, Meyers BF, Patel A, Robinson CG. Treatment outcomes in stage I lung cancer: a comparison of surgery and stereotactic body radiation therapy. $J$ Thorac Oncol 2015;10:1776-84.

50. Ricardi U, Frezza G, Filippi AR, Badellino S, Levis M, Navarria P, Salvi F, Marcenaro M, Trovò M, Guarneri A, Corvò R, Scorsetti M. Stereotactic ablative radiotherapy for stage I histologically proven non-small cell lung cancer: an Italian multicenter observational study. Lung Cancer 2014;84:248-53.

51. Onishi H, Shirato H, Nagata Y, Hiraoka M, Fujino M, Gomi K, Karasawa K, Hayakawa K, Niibe Y, Takai Y, Kimura T, Takeda A, Ouchi A, Hareyama M, Kokubo M, Kozuka T, Arimoto T, Hara R, Itami J, Araki T. Stereotactic body radiotherapy (SBRT) for operable stage I non-small-cell lung cancer: can SBRT be comparable to surgery? Int J Radiat Oncol Biol Phys 2011;81:1352-8.

52. Kastelijn EA, El Sharouni SY, Hofman FN, Van Putte BP, Monninkhof EM, Van Vulpen M, Schramel FM. Clinical outcomes in early-stage NSCLC treated with stereotactic body radiotherapy versus surgical resection. Anticancer Res 2015;35:5607-14.

53. Rosen JE, Salazar MC, Wang Z, Yu JB, Decker RH, Kim AW, Detterbeck FC, Boffa DJ. Lobectomy versus stereotactic body radiotherapy in healthy patients with stage I lung cancer. $J$ Thorac Cardiovasc Surg 2016;152:44-54.

54. Ezer N, Veluswamy RR, Mhango G, Rosenzweig KE, Powell CA, Wisnivesky JP. Outcomes after stereotactic body radiotherapy versus limited resection in older patients with early-stage lung cancer. $J$ Thorac Oncol 2015;10:1201-6.

55. Ginsberg RJ, Rubinstein LV. Randomized trial of lobectomy versus limited resection for T1 N0 non-small cell lung cancer. Lung Cancer Study Group. Ann Thorac Surg 1995;60:615-22.

56. Nakamura K, Saji H, Nakajima R, Okada M, Asamura H, Shibata T, Nakamura S, Tada H, Tsuboi M. A phase III randomized trial of lobectomy versus limited resection for small-sized peripheral nonsmall cell lung cancer (JCOG0802/WJOG4607L). Jpn J Clin Oncol 2010;40:271-4.

57. Suzuki K, Watanabe S, Mizusawa J, Moriya Y, Yoshino I, Tsuboi M Mizutani T, Nakamura K, Tada H, Asamura H; Japan Lung Cancer Surgical Study Group (JCOG LCSSG). Predictors of non-neoplastic lesions in lung tumours showing ground-glass opacity on thin-section computed tomography based on a multi-institutional prospective study†. Interact Cardiovasc Thorac Surg 2015;21:218-23.

58. Aokage K, Yoshida J, Hishida T, Tsuboi M, Saji H, Okada M, Suzuki $\mathrm{K}$, Watanabe S, Asamura H. Limited resection for early-stage nonsmall cell lung cancer as function-preserving radical surgery: a review. Jpn J Clin Oncol 2017;47:7-11.

59. NCT00499330. Phase III randomized study of lobectomy versus sublobar resection in patients with small peripheral stage IA non-small cell lung cancer. Available from: https:/www.georgiacancerinfo.org/ clinical-trials/lung-cancer/2591. [Last accessed on 28 Mar 2017].

60. Fernando HC, Landreneau RJ, Mandrekar SJ, Nichols FC, Hillman SL, Heron DE, Meyers BF, DiPetrillo TA, Jones DR, Starnes SL, Tan AD, Daly BD, Putnam JB Jr. Impact of brachytherapy on local recurrence rates after sublobar resection: results from ACOSOG Z4032 (Alliance), a phase III randomized trial for high-risk operable non-small-cell lung cancer. J Clin Oncol 2014;32:2456-62.

61. Takahashi N, Sawabata N, Kawamura M, Ohtsuka T, Horio H, Sakaguchi H, Nakayama M, Yoshiya K, Chida M, Hoshi E. Multicenter prospective study of sublobar resection for c-stage I non-small cell lung cancer patients unable to undergo lobectomy (KLSG-0801): complete republication. Gen Thorac Cardiovasc Surg 2016;64:470-5.

62. Timmerman R, Paulus R, Galvin J, Michalski J, Straube W, Bradley J, Fakiris A, Bezjak A, Videtic G, Johnstone D, Fowler J, Gore E, Choy H. Stereotactic body radiation therapy for inoperable early stage lung cancer. JAMA 2010;303:1070-6.

63. Nagata Y, Hiraoka M, Shibata T, Onishi H, Kokubo M, Karasawa K, Shioyama Y, Onimaru R, Kozuka T, Kunieda E, Saito T, Nakagawa K, Hareyama M, Takai Y, Hayakawa K, Mitsuhashi N, Ishikura $\mathrm{S}$. Prospective trial of stereotactic body radiation therapy for both operable and inoperable T1N0M0 non-small cell lung cancer: Japan 
Clinical Oncology Group Study JCOG0403. Int J Radiat Oncol Biol Phys 2015;93:989-96.

64. Chang JY, Senan S, Paul MA, Mehran RJ, Louie AV, Balter P, Groen HJ, McRae SE, Widder J, Feng L, van den Borne BE, Munsell MF, Hurkmans C, Berry DA, van Werkhoven E, Kresl JJ, Dingemans AM, Dawood O, Haasbeek CJ, Carpenter LS, De Jaeger K, Komaki R, Slotman BJ, Smit EF, Roth JA. Stereotactic ablative radiotherapy versus lobectomy for operable stage I non-small-cell lung cancer: a pooled analysis of two randomised trials. Lancet Oncol 2015;16:630-7.

65. Fernando HC, Timmerman R. American College of Surgeons Oncology Group Z4099/Radiation Therapy Oncology Group 1021: a randomized study of sublobar resection compared with stereotactic body radiotherapy for high-risk stage I non-small cell lung cancer. $J$ Thorac Cardiovasc Surg 2012;144:S35-8.

66. Timmerman R, McGarry R, Yiannoutsos C, Papiez L, Tudor K, DeLuca J, Ewing M, Abdulrahman R, DesRosiers C, Williams M, Fletcher J. Excessive toxicity when treating central tumors in a phase II study of stereotactic body radiation therapy for medically inoperable early-stage lung cancer. J Clin Oncol 2006;24:4833-9.

67. Sawabata N, Yokota S, Maeda H, Nakagawa M, Yamaguchi T, Okada T, Itho M. Diagnosis of solitary pulmonary nodule: optimal strategy based on nodal size. Interact Cardiovasc Thorac Surg 2006;5:105-8.

68. Sawabata N, Ohta M, Maeda H. Fine-needle aspiration cytologic technique for lung cancer has a high potential of malignant cell spread through the tract. Chest 2001;120:1595-8.

69. Inoue M, Honda O, Tomiyama N, Minami M, Sawabata N, Kadota
Y, Shintani Y, Ohno Y, Okumura M. Risk of pleural recurrence after computed tomographic-guided percutaneous needle biopsy in stage I lung cancer patients. Ann Thorac Surg 2011;91:1066-71.

70. Kashiwabara K, Semba H, Fujii S, Tsumura S. Preoperative percutaneous transthoracic needle biopsy increased the risk of pleural recurrence in pathological stage I lung cancer patients with subpleural pure solid nodules. Cancer Invest 2016;34:373-7.

71. Sawabata N, Maeda H, Ohta M, Hayakawa M. Operable non-small cell lung cancer diagnosed by transpleural techniques: do they affect relapse and prognosis? Chest 2001;120:1595-8.

72. Nakajima J, Sato H, Takamoto S. Does preoperative transbronchial biopsy worsen the postsurgical prognosis of lung cancer? A propensity score-adjusted analysis. Chest 2005;128:3512-8.

73. Hattori A, Matsunaga T, Takamochi K, Oh S, Suzuki K. Neither maximum tumor size nor solid component size is prognostic in partsolid lung cancer: impact of tumor size should be applied exclusively to solid lung cancer. Ann Thorac Surg 2016;102:407-15.

74. Tsurugai Y, Kozuka T, Ishizuka N, Oguchi M. Relationship between the consolidation to maximum tumor diameter ratio and outcomes following stereotactic body radiotherapy for stage I non-small-cell lung cancer. Lung Cancer 2016;92:47-52.

75. The prospective observational study of lung wedge resection for cT1a,1bN0M0 non-small lung cancer patients. Available from: https://upload.umin.ac.jp/cgi-open-bin/ctr/ctr.cgi?function=brows\& action $=$ brows \& recptno $=\mathrm{R} 000027991 \&$ type $=$ summary \&language $=\mathrm{J}$. [Last Accessed on 8 Jan 2017]. 